Research Article

\title{
Influence of Organic Matter Content on Engineering Properties of Clays
}

\author{
Yue Gui $\mathbb{D}^{1},{ }^{1}$ Qiumin Zhang $\left(\mathbb{D},{ }^{1}\right.$ Xiaqiang Qin $\left(\mathbb{D},{ }^{2}\right.$ and Jianfei Wang ${ }^{3}{ }^{3}$ \\ ${ }^{1}$ Department of Civil Engineering, Kunming University of Science and Technology, Kunming, Yunnan 650504, China \\ ${ }^{2}$ China MCC20 Group Corp. Ltd., Shanghai 201900, China \\ ${ }^{3}$ Yunnan Construction and Investment Holding Group Co., Ltd., Kunming, Yunnan 650504, China
}

Correspondence should be addressed to Yue Gui; gydrgui@kmust.edu.cn

Received 5 October 2020; Revised 28 December 2020; Accepted 24 January 2021; Published 17 February 2021

Academic Editor: Jia-wen Zhou

Copyright ( 2021 Yue Gui et al. This is an open access article distributed under the Creative Commons Attribution License, which permits unrestricted use, distribution, and reproduction in any medium, provided the original work is properly cited.

\begin{abstract}
Most natural sedimentary clay contains organic matter, and even a small amount of organic matter will have a great impact on the physical and mechanical properties of clay. In order to clarify the influence of organic matter content on clay soil, the illite-quartz mixture was mixed with natural amorphous peat soil (organic matter content is 50\%) in different proportions for studying the influence of different organic matter contents on the physical properties (specific gravity, $G_{s}$; moisture content, $w$; void ratio, $e$; liquid limit, $w_{L}$; plastic limit, $w_{p}$; plasticity index, $I_{p}$ ) and shear characteristics (cohesion, $c$; friction angle, $\varphi$ ) of clay soil. The experimental results found that, with the change of organic matter content, the specific gravity and void ratio of clay changed linearly, while the water content, Atterberg limit, shear strength, cohesion, and friction angle changed nonlinearly with the increase of organic matter content. Moisture content and Atterberg limit have a turning point when OC $=7.5 \%$. Shear strength, cohesion, and friction angle all have obvious turning points when $\mathrm{OC}=7.5 \%$ and $\mathrm{OC}=37.5 \%$. The variation of moisture content and Atterberg limit with organic matter content indicates that $\mathrm{OC}=7.5 \%$ may be the limit value for the different forms of organic matter in the clay. When OC $\leq 7.5 \%$, the organic matter in clay is in the bound state; when OC $>7.5 \%$, the bound organic matter reaches saturation; and the free organic matter gradually increases. The change law of shear strength characteristics with organic matter content shows that the interaction between minerals and organic matter exhibits different shear characteristics under different organic matter content. When OC $\leq 7.5 \%$, clay shows mineral properties, when $7.5 \%<$ OC $\leq 37.5 \%$, clay shows mineralfree organic matter properties, and when OC $>37.5 \%$, clay shows free organic matter properties.
\end{abstract}

\section{Introduction}

Naturally, sedimentary clay often contains organic matter, but the content and type of organic matter have significant differences [1-4]. Different contents and different organic matter forms have significant effects on the structure and properties of mineral soil. In road construction, the road will inevitably cross the high organic soil or peatland area. The organic soil and peat with high moisture content, high compressibility, and low bearing capacity are not suitable for constructing embankments and highways, so the use of Preloading methods, Deep cement mixing, and Excavation-Replacement methods to treat the subgrades is becoming more common [5-7]. However, how to evaluate the influence of organic matter content on soil engineering properties of clay is still not well understood. The study of the impact of the content and type of organic matter on clay's engineering properties is significant in guiding roadbed engineering design and construction [8-10].

Many scholars have used different methods to study the influence of organic matter on soil's engineering properties. According to the summary of the research methods of the influence of organic matter on soil's engineering properties, the main research methods can be organized into 3 classes. The first method is to collect soil samples with different organic matter contents in multiple areas and then analyze the influence of organic matter contents on the soil's engineering properties. For example, Odell et al. [11] studied 26 groups of different organic soil in Illinois, and the 
influence of organic matter content on the Atterberg limit was analyzed. It was found that the Atterberg limit increased with the increase of organic matter content. They also found that organic matter was responsible for most of the variability observed in the samples' plastic limit values; Bush and Keller [12] studied the physical properties of sediments in the two areas of Peru-Chile continental slope and eastern Nazca Plate. The results show that the moisture content and Atterberg limit of sediment are positively correlated with organic matter content; Bennett et al. [13] studied the relationship between organic matter and sediment properties in the two continental margins of the United States. It has been found that moisture content, Atterberg limit, and particle content closely related to organic matter content. However, they concluded that the correlation between organic matter content and Atterberg was not strong enough to imply significant interdependence. Due to different sources of organic matter and different mineral compositions in organic soil in different regions, the biggest drawback of this method is the case that while the organic matter content changes, the mineral and organic matter composition of the soil also change. Another common method is to prepare organic clay composites by adding organic compounds to pure mineral soil. For example, Olgun and Yildiz [14] mixed methanol, ethanol, isopropanol, acetic acid, and distilled water in different proportions and added them to the soil collected from Aksaray city of Turkey to prepare organic soil with different organic matter contents. The Atterberg limit of soil was measured, and triaxial compression tests were performed. The results showed that the liquid limit and plasticity index decreased with increasing ratio of organic matter content to moisture content, and the soil with methanol as the organic matter has a lower compression index and swelling index than other organic soils. Zeng et al. [15] mixed water-insoluble organic matter (humic acid) and water-soluble three organic matters (humic acid phthalein, potassium humate, and fabric acid) with eight clays (six natural clays and two pure mineral clays). The organic compounds of different minerals and different organic matter were prepared, and the physical properties of various organic compounds were studied. The results show that the Atterberg limits of clay with different minerals and different organic matter compositions are quite different. However, this organic compound's composition differs significantly from that of natural organic matter in the soil, which cannot completely take into account the actual situation. Some scholars also deal with organic soil by chemical means to regulate the organic matter in the soil. For example, Roshid and Brown [16] used hydrogen peroxide to remove organic substances from the original soil and then added humic acid to prepare organic soil with organic matter content of $0 \% \sim 4 \%$, and the engineering properties of soil with different organic matter contents were studied. The results showed that the plasticity, undrained shear strength, and compressibility of soil increased with organic matter content. Booth and Dahl [17] removed the organic matter from sedimentary soil by using hydrogen peroxide solution and then mixed them with original sedimentary soil in proportion to prepare samples of different organic matter content $(0.57 \% \sim 3.2 \%)$. The results show that organic matter has a significant correlation with liquid limit, plasticity index, and specific gravity. However, this method was complex, time-consuming, and laborious and was only suitable for soil samples with minimal organic content.

Besides, the current research on the relationship between the organic matter and the engineering properties of clays is still concentrated in a relatively small range $(0 \% \leq$ OC $\leq 20 \%$ ) [11-13, 16-19]. For example, Hameedi et al. [20, 21] and Fattah et al. [22] studied the engineering properties of clay with organic matter content of $2 \sim 15 \%$ in southern Iraq. However, for special clays such as organic soil and peat, the content of soil organic matter mostly exceeds 20\% [23-25]. Aiming at the above shortcomings, the illite-quartz mixture and natural amorphous peat soil (50\% organic matter content) were mixed in different proportions to prepare 12 sets of clay soils with the same mineral composition and different organic matter content $(0 \% \sim 50 \%)$. This article's primary purpose is to clarify the influence of organic matter content on clay soil's physical and mechanical properties. On the other hand, this study analyzed the threshold of different organic matter (bound and free) forms and the influence of the interaction between organic matter and minerals in different forms on the shear characteristics of clayey soil.

\section{Materials and Methods}

2.1. Materials. Natural peat soil samples are collected from the engineering site near Dianchi Lake in Kunming City, Yunnan Province, China, as shown in Figures 1(a) and 1(b). Manual sampling is shown in Figure 1(c). The sample is shown in Figure 1(d). The test results are shown in Table 1. Among them, the ignition loss $\left(w_{u}\right)$ was determined for all peat soil samples to ASTM (D2974 2014) [26]; the fibers' content $\left(w_{f}\right)$ was determined for all peat soil samples to ASTM (D1997-13) [27], and according to ASTM (D4427 2013) [28] classification methods, it can be judges that the peat soil belongs to amorphous peat soil. X-ray diffractometry (XRD) tests were performed for identifying the mineralogical compositions of the peat soil. Specimens for XRD tests were prepared following the methods described by Whittig and Allardice [29]. Figure 2 presents the X-ray diffraction patterns of peat soil. The predominant clay mineral of the natural peat soil investigated is illite, with a proportion varying within the range of $75 \%$ to $85 \%$, followed by quartz $(10 \% \sim 20 \%)$. According to the content ratio of illite to quartz in the amorphous peat soil, the mass ratio of illite to quartz in the mixture $(d \leq 0.038 \mathrm{~mm})$ added to the test sample in this paper is $4: 1$. The mineral components of peat soil, illite, and quartz are shown in Table 2.

2.2. Samples Preparation and Test Methods. Remove residual fibers in the amorphous peat soil before proceeding with the sample, and distilled water was added to prepare a slurry sample with a water content of 2.0 times the liquid limit. The organic content of the slurries after fully mixing was measured to be $50 \%$. The slurries with an initial organic 


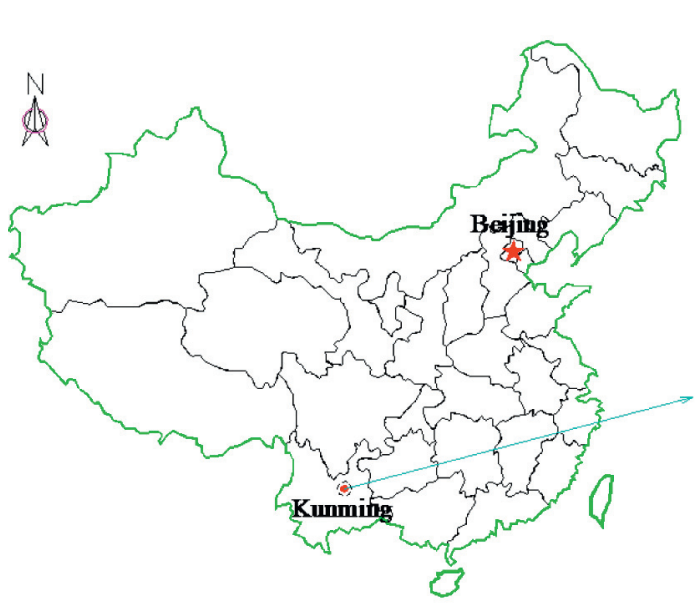

(a)

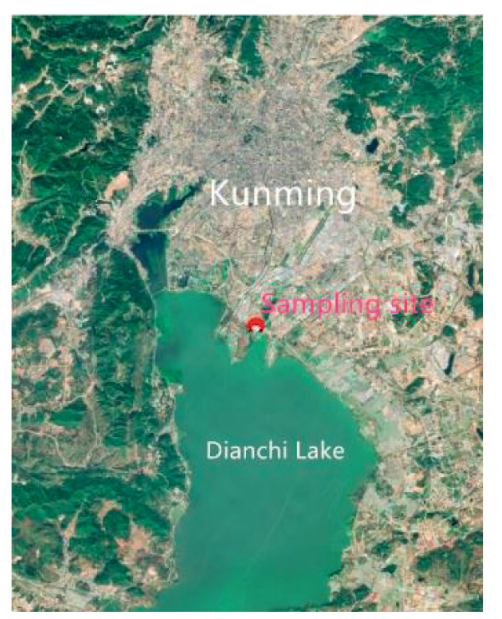

(b)

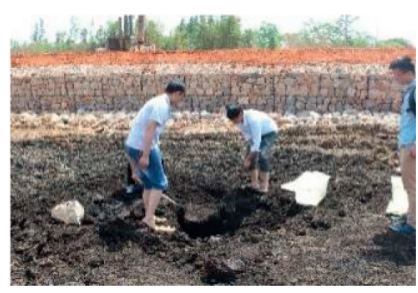

(c)

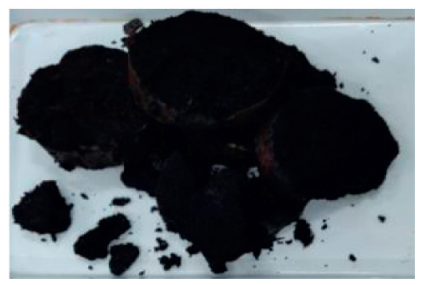

(d)

Figure 1: Sampling location, sampling process, and sample of peat soil. (a, b) Sampling site location. (c) Manual sampling. (d) Peat soil samples.

TABLE 1: Basic physical properties of peat soil.

\begin{tabular}{lccccccc}
\hline$W(\%)$ & $e$ & $w_{L}(\%)$ & $w_{P}(\%)$ & $G s$ & $\rho\left(\mathrm{g} \cdot \mathrm{cm}^{-3}\right)$ & $w_{u}(\%)$ & $w_{f}(\%)$ \\
\hline 237.4 & 3.8 & 136.0 & 387.0 & 1.65 & 1.04 & $48.1-50.8$ & $0.5-2.3$ \\
\hline
\end{tabular}

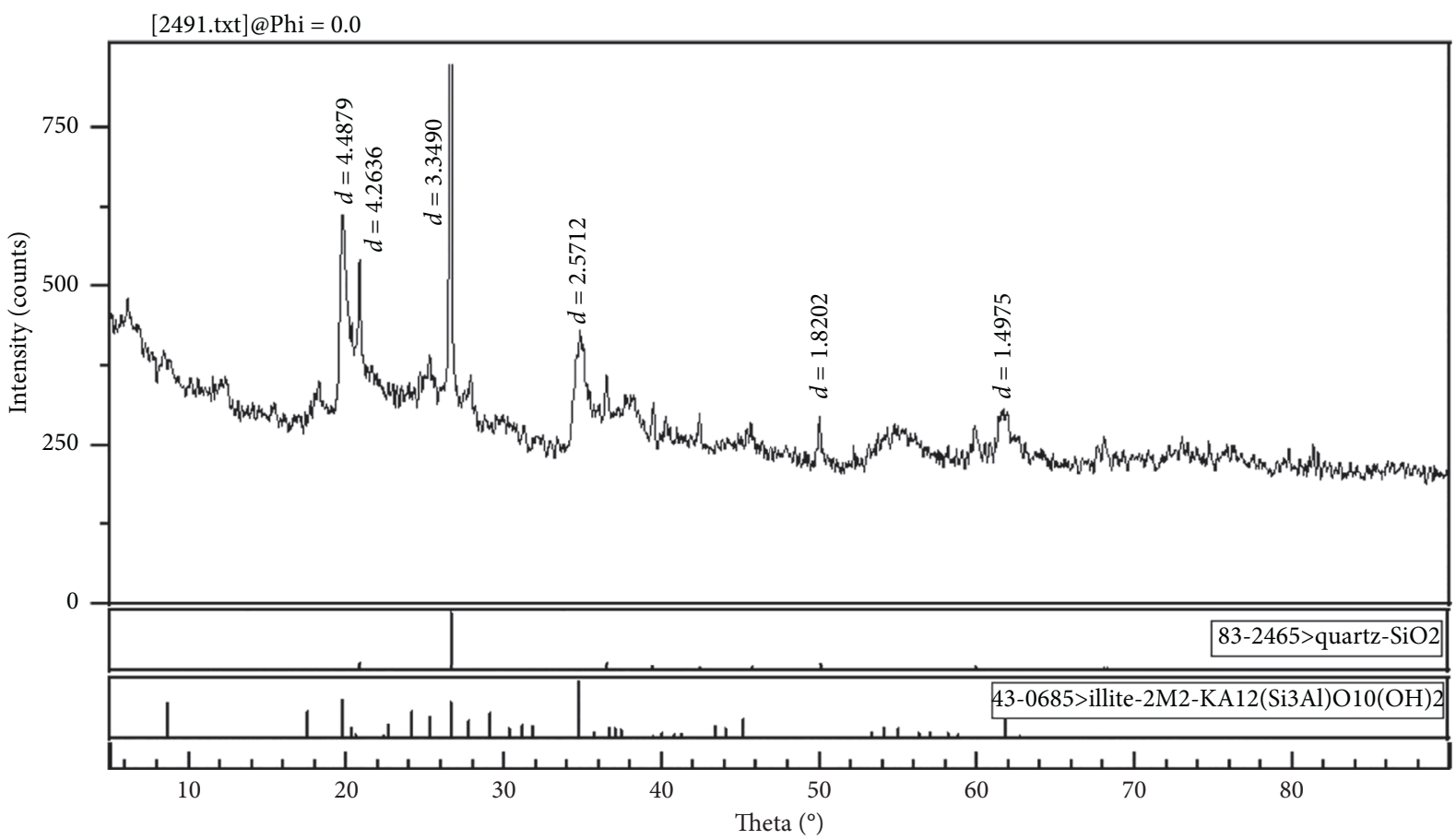

Figure 2: X-ray diffraction pattern of peat soil.

matter content of $50 \%$ were mixed with illite-quartz (with an organic matter content of $0 \%$ ) in the required proportions to prepare samples with organic matter content ranging from $0 \%$ to $50 \%$ (as shown in Figure 3 ). The specimens were prepared by preconsolidating the clay slurries for $24 \mathrm{~h}$. The slurries were preconsolidated by placing them into a cell
$61.8 \mathrm{~mm}$ in diameter and $40 \mathrm{~mm}$ in height. The specimens were preconsolidated by pressure of up to $50 \mathrm{kPa}$ by gradual pressure increase $(12.5,25.0$, and $50.0 \mathrm{kPa})$ before measuring physical and mechanical parameters.

The physical properties measured consist of the specific gravity $\left(G_{s}\right)$, the water content $(w)$, and the Atterberg limits 
TABLE 2: Chemical composition of peat soil, illite, and quartz sand.

\begin{tabular}{lccc}
\hline Name & Peat soil & Illite & Quartz sand \\
\hline $\mathrm{SiO}_{2}$ & 40.25 & 78.00 & $>98.00$ \\
$\mathrm{Al}_{2} \mathrm{O}_{3}$ & 21.37 & 12.33 & 1.00 \\
$\mathrm{TiO}_{2}$ & 7.41 & 1.20 & \\
$\mathrm{~K}_{2} \mathrm{O}$ & 1.55 & 7.80 & \\
$\mathrm{Na}_{2} \mathrm{O}$ & 2.48 & & \\
$\mathrm{MgO}$ & 1.78 & & \\
$\mathrm{MnO}$ & 1.53 & & \\
Others & 0.21 & & \\
\hline
\end{tabular}

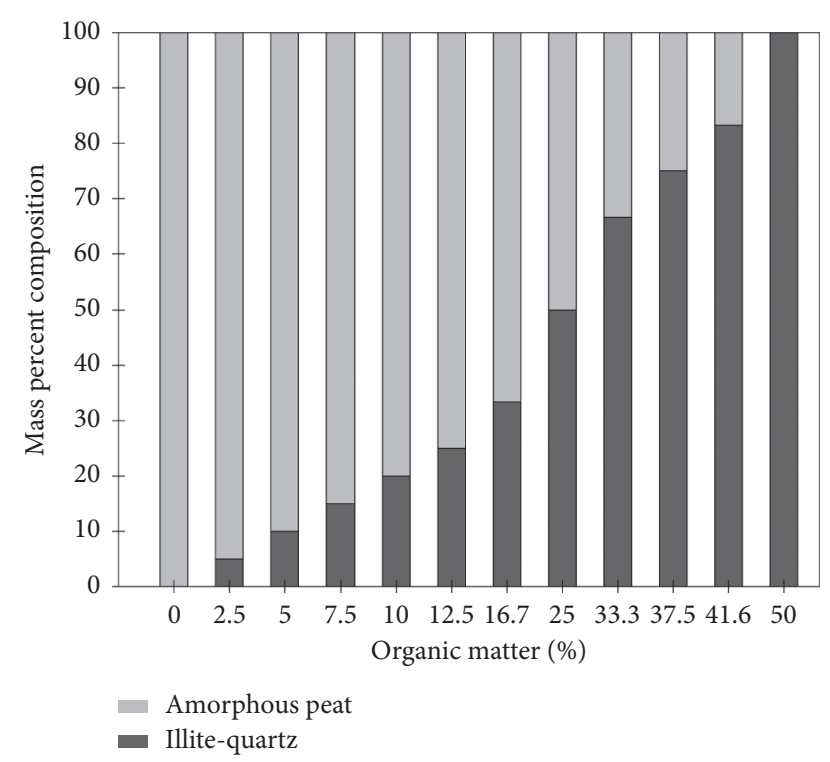

FIgURE 3: Proportion of samples with different organic matter content.

(liquid limit $w_{L}$; plastic limit $w_{P}$; and plastic index $I_{P}$ ). The tests are undertaken according, respectively, to the test standards ASTM D854 [30]; ASTM (D2974-14) [26]; ASTM (D4318-17) [31].

It should be noted that until now a specific shear test method has not been introduced for peat soils to determine their shear strength parameters. But among conventional shear tests, the ring shear and direct simple shear tests in which the effect of fibers on test procedure is low were found to be more suitable [32]. Hence, this paper uses the direct shear test to test the shear strength of the specimens. Specimens are precompressed (the applied prepressure $\left(\sigma_{v}\right)$ was $50 \mathrm{kPa}, 100 \mathrm{kPa}, 150 \mathrm{kPa}$, and $200 \mathrm{kPa}$, resp.) before the shear test. The test is performed according to test standard ASTM (D3080/D3080 M-11) [33].

\section{Results and Discussion}

3.1. Physical Properties. Before studying the influence of organic matter content on the shear properties of clay, the basic physical properties of each group of samples were evaluated. The underlying physical properties are shown in Table 3. The relation curve between different organic matter content and each index was drawn to further analyze each
TABLe 3: Basic physical properties of samples.

\begin{tabular}{lccccccc}
\hline No. & $w_{u}(\%)$ & $G s$ & $e$ & $W(\%)$ & $w_{L}(\%)$ & $w_{P}(\%)$ & $I_{P}(\%)$ \\
\hline 1 & 0.0 & 2.75 & 0.9 & 58.0 & 66 & 41 & 25 \\
2 & 2.5 & 2.64 & 1.0 & 63.0 & 69 & 42 & 27 \\
3 & 5.0 & 2.58 & 1.2 & 69.0 & 73 & 44 & 29 \\
4 & 7.5 & 2.52 & 1.2 & 73.0 & 81 & 46 & 35 \\
5 & 10.0 & 2.48 & 1.3 & 77.0 & 97 & 57 & 39 \\
6 & 12.5 & 2.39 & 1.5 & 87.2 & 136 & 76 & 61 \\
7 & 16.7 & 2.25 & 1.8 & 109.2 & 150 & 77 & 93 \\
8 & 25.0 & 2.04 & 2.2 & 139.9 & 200 & 97 & 104 \\
9 & 33.3 & 1.91 & 2.6 & 185.1 & 292 & 114 & 178 \\
10 & 37.5 & 1.83 & 3.3 & 211.5 & 316 & 128 & 188 \\
11 & 41.6 & 1.75 & 3.6 & 225.3 & 349 & 133 & 216 \\
12 & 50.0 & 1.65 & 3.8 & 247.4 & 387 & 136 & 242 \\
\hline
\end{tabular}

physical index's change rule under different organic matter content.

3.1.1. Effect of Organic Matter Content on Specific Gravity. In previous studies $[12,24]$, the organic matter and mineral components of peat soil samples from different regions are quite different, the specific gravity of organic soil is not significantly correlated with the organic matter content, and the data is highly discrete. This may be due to the differences in minerals and organic matter and the small range of organic matter content. The effect of organic matter content on the specific gravity value $\left(G_{s}\right)$ is evident from Figure 4 . The $G_{s}$ values of the clays decrease linearly with the increase of organic matter content and have a high correlation $\left(R^{2}=0.997\right)$. The organic matter content increased from $0 \%$ to $50 \%$, and the $G_{s}$ values of the sample decreased from 2.75 to 1.65. The decrease in $G_{s}$ values with the increase of organic matter is due mainly to the low value of the specific gravity of the organic matter $[16,17,34,35]$.

3.1.2. Effect of Organic Matter Content on Void Ratio. In Figure 5, the void ratio versus the organic matter content of the samples is reported. It can be seen that the void ratio increases with increasing organic matter content, and the correlation is very high $\left(R^{2}=0.983\right)$. Hamouche and Zentar [36] studied sediment with different organic matter and obtained the result that the void ratio increased with organic matter.

\subsubsection{Effect of Organic Matter Content on Moisture Content.} Hamouche and Zentar [36] found that the relationship between moisture content and organic matter content increases linearly. The relationship between organic matter content and moisture content in this paper is shown in Figure 6. It is worth noting that the relationship between moisture content and organic matter content is not a single linear increase. When OC $=7.5 \%$, the straight line turns, and the slope increases from 2.040 to 4.497 . Humus has a huge specific surface area and hydrophilic groups, and its strong water absorption is the main reason for the increase of soil moisture content [37]. 


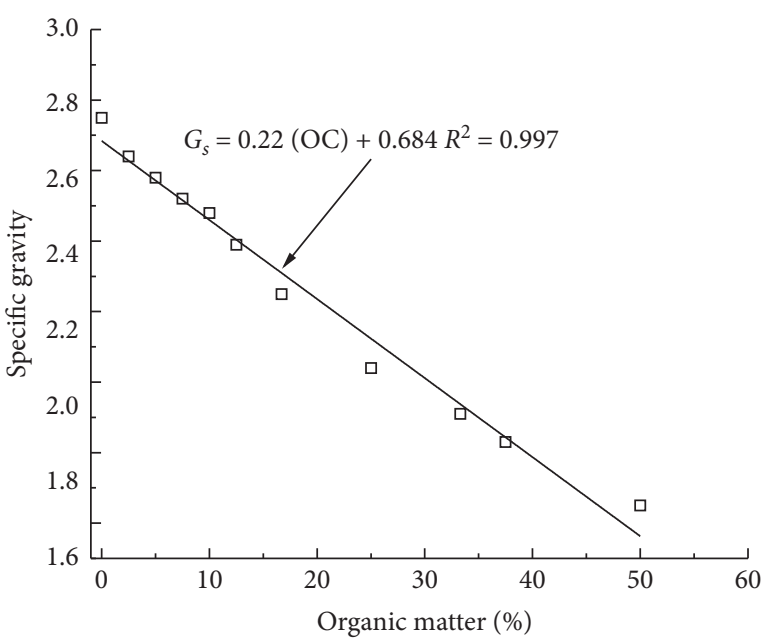

FIGURE 4: Change of specific gravity against organic matter content.

3.1.4. Effect of Organic Matter Content on Atterberg Limit. At present, regarding the relationship between the liquid limit and plastic limit and the change of organic matter content, there is a consensus that the liquid limit and plastic limit increase linearly with the increase of organic matter content, as shown in Table 4. It can be seen from the table that although the organic matter content has a high correlation with the liquid limit and plastic limit, the range of the organic matter content studied is relatively small. As for the plasticity index $\left(I_{P}\right)$ of organic soil, many researchers have found that $I_{P}$ increases with OC, but the correlation is not significant $[11,13,16,38,39]$.

The relationship between the liquid limit, plastic limit, and plasticity index of clay in this paper with the organic matter content is shown in Figures 7(a)-7(c). It can be seen from Figure 7 that liquid limit, plastic limit, and plasticity index increase with the increase of organic matter content. It is worth noting that the straight line is divided into two stages $(\mathrm{OC}=7.5 \%)$. When $\mathrm{OC} \leq 7.5 \%$, the organic matter increases by $1 \%$, and the liquid limit, plastic limit, and plasticity index increase by $1.89 \%, 0.62 \%$, and $1.26 \%$, respectively; when OC $>7.5 \%$, the organic matter increases by $1 \%$, and the liquid limit, and plastic limit, and plasticity index increased by $7.48 \%, 2.15 \%$, and $5.21 \%$, respectively.

\subsection{Effect of Organic Matter Content on Shear Properties.} Shear strength tests were carried out on 12 groups of samples to evaluate the influence of different organic content on the shear strength and related peat soil parameters. The shear strength-displacement curve of cohesive soil when the prepressure is $50 \mathrm{kPa}, 100 \mathrm{kPa}, 150 \mathrm{kPa}$, and $200 \mathrm{kPa}$ is shown in Figures 8(a)-8(d), respectively. It can be seen from Figure 8 that the shear strength-displacement curve has no obvious peak, and Badv and Sayadian [25] also obtained similar research results. It is worth noting that the shear strength-displacement curve gradually moves down with the increase of organic matter content at the same vertical pressure. This phenomenon becomes more obvious with the increase of vertical pressure.

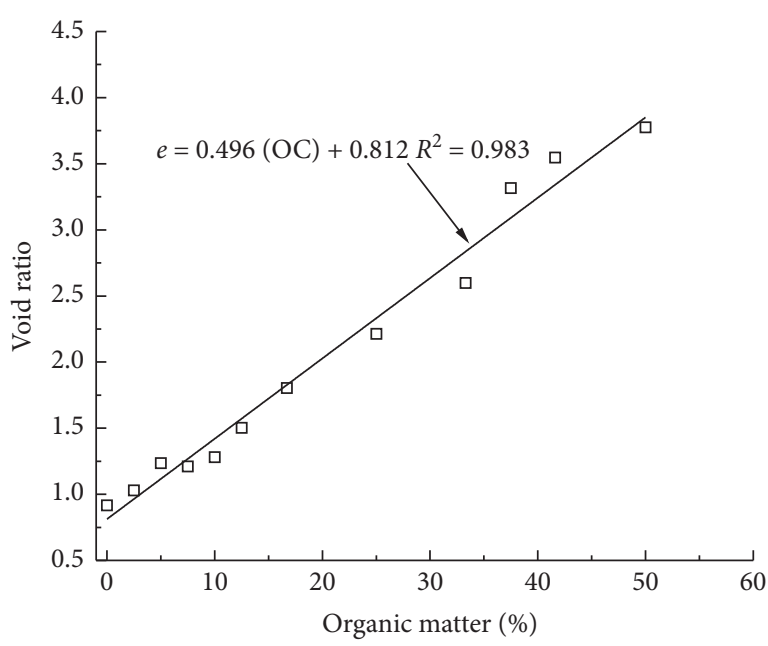

FIgURE 5: Change of void ratio against organic content.

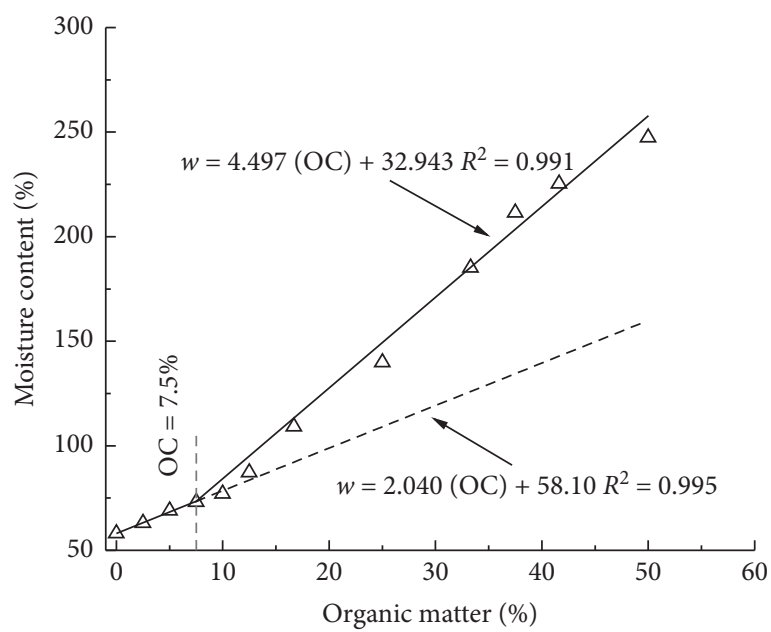

FIGURE 6: Change of moisture content against organic content.

According to ASTM (D3080/D3080M-11) standard [33], when there is no peak value, the shear stress corresponding to the shear displacement of $10 \%$ is taken as the shear stress when the specimen fails. Table 5 shows the shear strength and shear strength indexes (cohesion and friction angle) of 12 groups of samples under different consolidation pressures. The relationship between shear strength, shear strength parameters, and organic matter content was drawn to analyze further the change rule of shear characteristics under different organic matter content.

3.2.1. Effect of Organic Matter Content on Shear Strength. Figure 9 plots the change curve of the sample's shear strength with the organic matter content under different vertical pressures. It can be seen from the figure that the shear strength of clay gradually decreases with the increase of organic matter content. It is worth noting that when $\mathrm{OC}=7.5 \%$ and $\mathrm{OC}=37.5 \%$, the straight line has a turning point and the rate of change of shear strength slows down. 
TABLE 4: Some research results on the relationship between organic matter content and liquid limit $\left(w_{L}\right)$ and plastic limit $\left(w_{p}\right)$.

\begin{tabular}{|c|c|c|c|c|c|}
\hline Data sources & OC $(\%)$ & $w_{L}(\%)$ & $R^{2}$ & $w_{P}(\%)$ & $R^{2}$ \\
\hline Odell et al. [11] & $0 \% \sim 6 \%$ & $w_{L}=4.937(\mathrm{OC})+36.01$ & - & $w_{P}=3.736(\mathrm{OC})+19.25$ & - \\
\hline Booth and Dahl [17] & $0 \% \sim 4 \%$ & $w_{L}=11.31(\mathrm{OC})+80.04$ & 0.94 & $w_{P}=4.157(\mathrm{OC})+41.05$ & 0.92 \\
\hline Adejumo [39] & $0 \% \sim 25 \%$ & $w_{L}=1.024(\mathrm{OC})+42$ & 0.98 & $w_{P}=0.521(\mathrm{OC})+25.1$ & 0.97 \\
\hline \multirow[t]{2}{*}{ Hamouche and Zentar [40] } & $0 \% \sim 15 \%$ & $w_{L}=1.89(\mathrm{OC})+25.13$ & 0.99 & $w_{P}=1.80(\mathrm{OC})+16.7$ & 0.95 \\
\hline & $5 \% \sim 15 \%$ & $w_{L}=3.08(\mathrm{OC})+15.61$ & 0.96 & $w_{P}=3.00(\mathrm{OC})+4.32$ & 0.96 \\
\hline
\end{tabular}

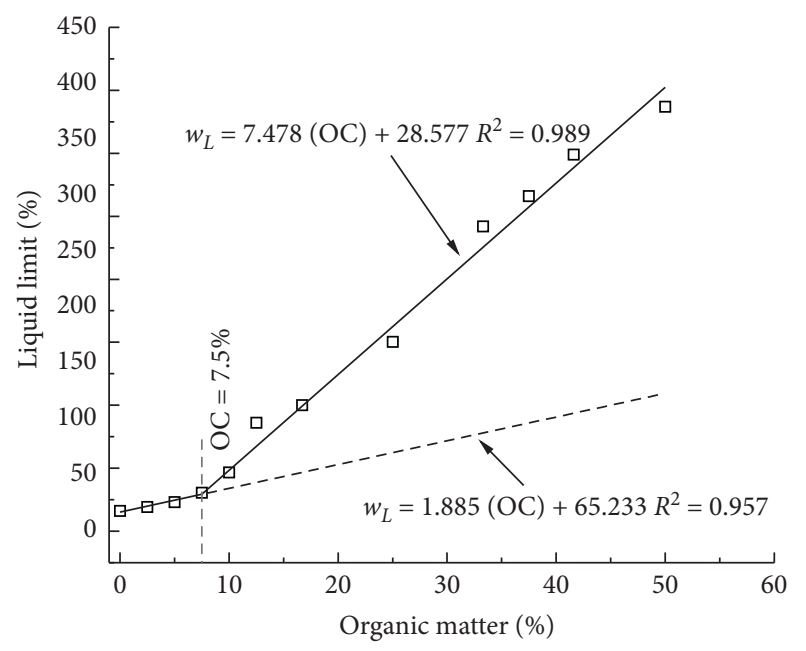

(a)

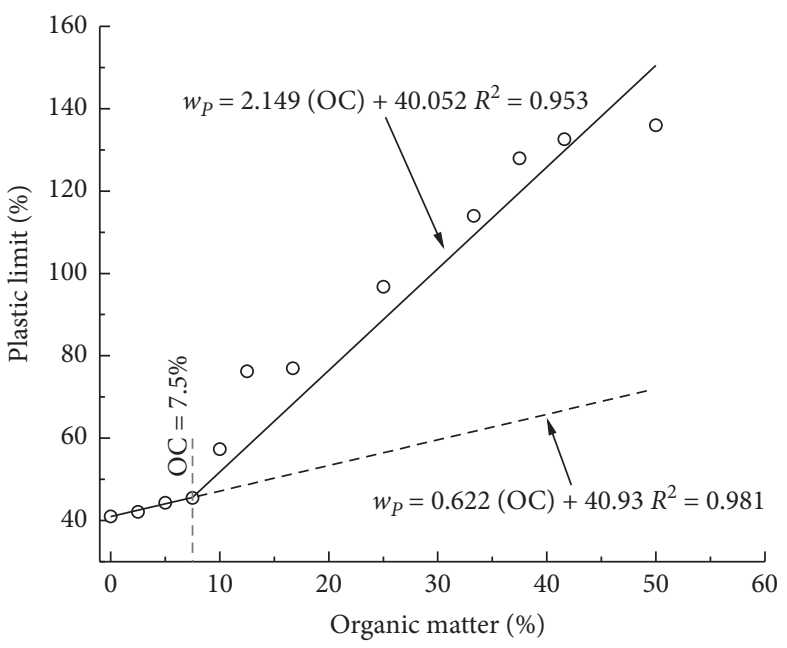

(b)

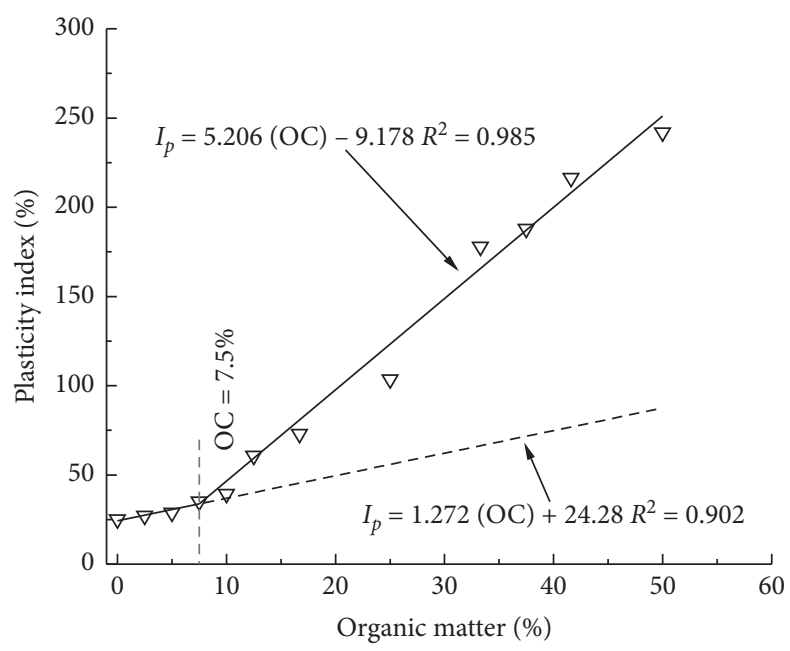

(c)

FIGURE 7: Change of Atterberg limit against organic content: (a) liquid limit, (b) plastic limit, and (c) plasticity index.

3.2.2. Effect of Organic Matter Content on Cohesion and Friction Angle. Pulat and Yukselen-Aksoy [41] conducted shear tests on municipal solid wastes from Europe, Turkey, and the United States of America and found that the internal friction angle decreases linearly with the increase of organic matter content, with a correlation of 0.6. Although the cohesion force increases with the organic matter content, there is no explicit function relationship; Braida et al. [42] studied the clay in five different areas of Santa Maria and found that the internal friction angle decreased linearly with the increase of organic matter content, and the correlation was in the range of 0.1 to 0.6 . They also believe that cohesion has nothing to do with organic content; Edil and Wang [43] analyzed the relationship between effective friction angle and organic matter content based on the existing research data of organic soil and peat in Minnesota and Wisconsin and found that the data has great dispersibility.

From the above research results, it can be found that the correlation between organic matter and the friction angle is relatively weak, and the data are discrete. The relationship between organic content and cohesion is very vague. The 

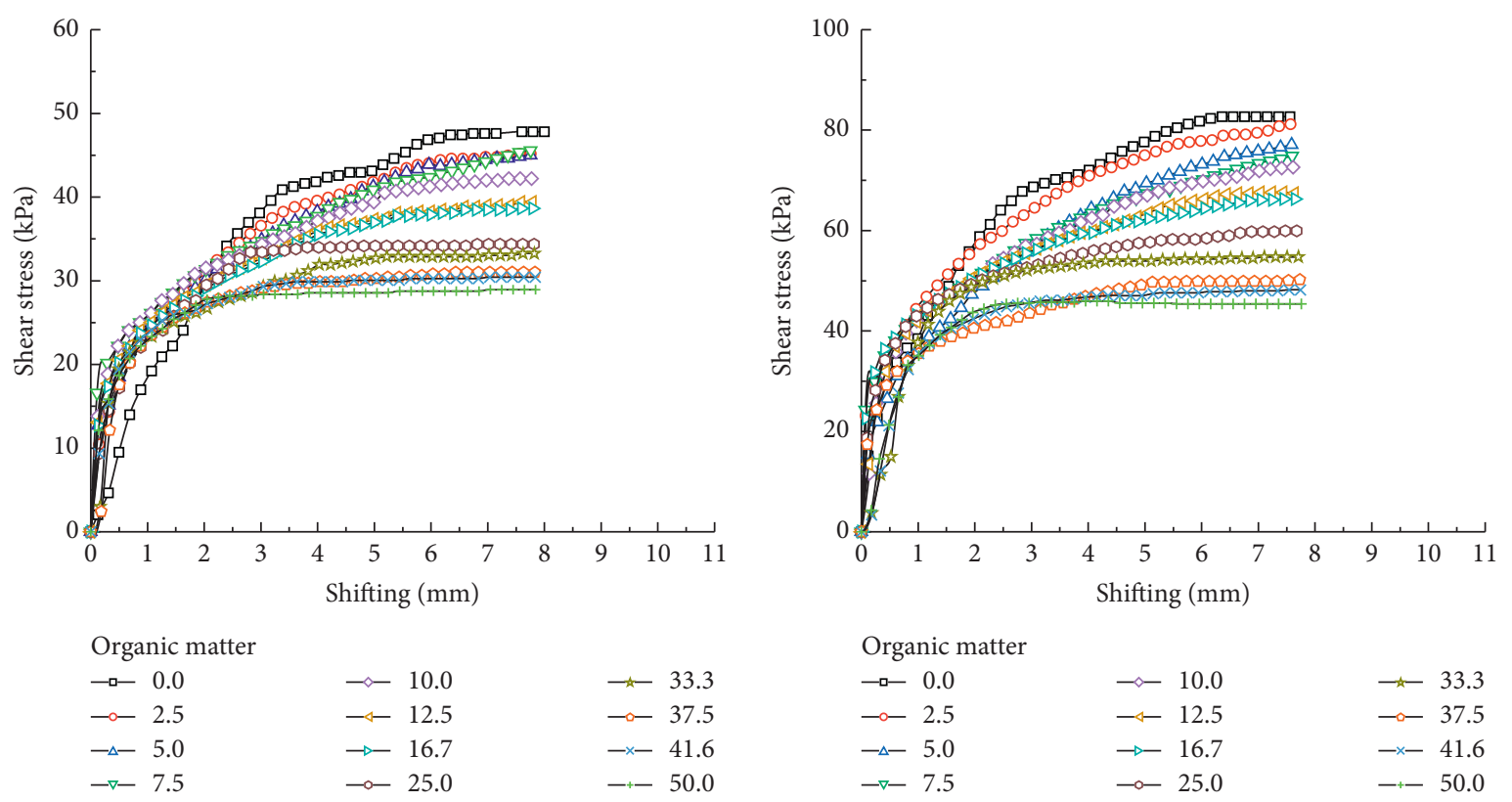

(a)

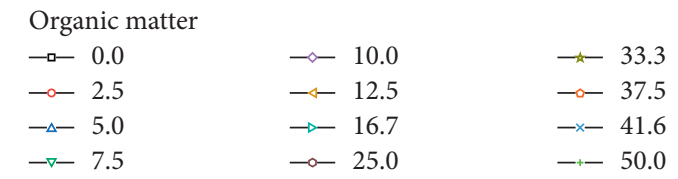

(b)
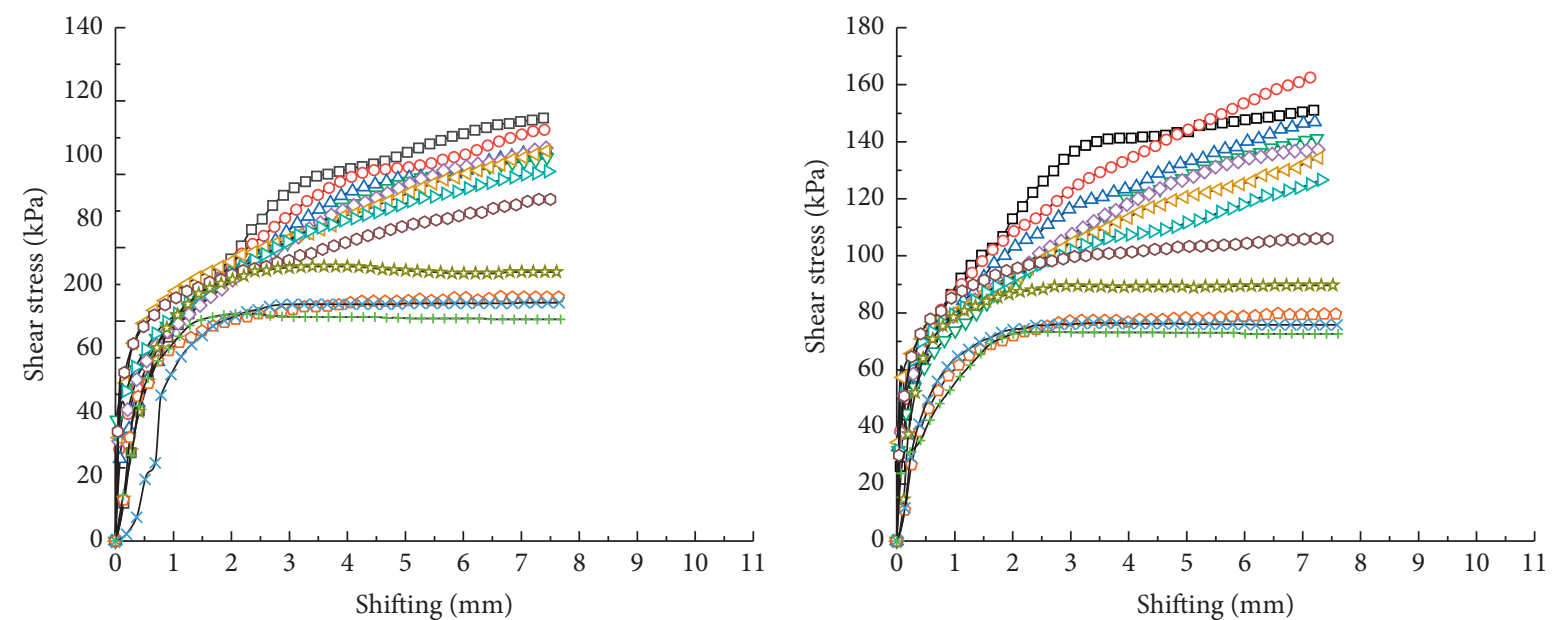

\begin{tabular}{|c|c|c|}
\hline Organic matter & & \\
\hline$\rightarrow 0.0$ & $\neg-10.0$ & -ג一 33.3 \\
\hline$\multimap-2.5$ & $-\triangleleft-12.5$ & $\multimap 37.5$ \\
\hline$-\Delta-5.0$ & $\rightarrow-16.7$ & $-x-41.6$ \\
\hline$-\nabla-7.5$ & $-\circ-25.0$ & 50.0 \\
\hline
\end{tabular}

(c)

\begin{tabular}{|c|c|c|}
\hline Organic matter & & \\
\hline$\rightarrow-0.0$ & $-\diamond \quad 10.0$ & 一 -33.3 \\
\hline$\multimap 2.5$ & $-\triangleleft-12.5$ & $\multimap 37.5$ \\
\hline$-\Delta-5.0$ & $\rightarrow-16.7$ & $-x-41.6$ \\
\hline$-\nabla-7.5$ & $\multimap-25.0$ & --50.0 \\
\hline
\end{tabular}

(d)

FIgURE 8: Shear strength and shear displacement curves of 12 groups of samples under different vertical pressures. (a) The prepressure is $50 \mathrm{kPa}$. (b) The prepressure is $100 \mathrm{kPa}$. (c) The prepressure is $150 \mathrm{kPa}$. (d) The prepressure is $200 \mathrm{kPa}$.

author believes that this is caused by differences in minerals and organic components in the organic soil collected from different regions. In this paper, the variation of cohesion with organic matter content is shown in Figure 10(a), and the change rule of friction angle with organic matter content is shown in Figure 10(b). As the content of organic matter increases, the cohesion of clay increases and the angle of internal friction decreases. It is worth noting that the straight line turns when $\mathrm{OC}=7.5 \%$ and $\mathrm{OC}=37.5$, and the absolute value of the straight line slope gradually decreases. The change rate of clay cohesion and friction angle slows down.
3.3. Discussion. Organic matter in amorphous peat soil is mainly humus. The specific gravity of humus is smaller than that of minerals, and its morphology is similar to colloid and has a larger specific surface area and more hydrophilic groups than minerals. In organic soil, humus and mineral soil particles are not simply mechanically mixed, and complex physical and chemical reactions occur between them to form an organic matter-mineral complex. Minerals and humus will form a mineral-humus complex through anion exchange, ligand exchange surface coordination, hydrophobicity, entropy, cationic bridging, and hydrogen 
TABLE 5: Shear properties of samples.

\begin{tabular}{|c|c|c|c|c|c|c|c|}
\hline \multirow{2}{*}{ No. } & \multirow{2}{*}{$w_{u}(\%)$} & \multicolumn{4}{|c|}{ Shear strength $(\mathrm{kPa})$} & \multirow{2}{*}{$c(\mathrm{kPa})$} & \multirow{2}{*}{$\varphi\left(^{\circ}\right)$} \\
\hline & & $\sigma_{v}=50 \mathrm{kPa}$ & $\sigma_{v}=100 \mathrm{kPa}$ & $\sigma_{v}=150 \mathrm{kPa}$ & $\sigma_{v}=200 \mathrm{kPa}$ & & \\
\hline 1 & 0 & 40.0 & 72.9 & 105.7 & 138.6 & 7.2 & 33.3 \\
\hline 2 & 2.5 & 39.0 & 70.4 & 101.8 & 133.1 & 7.7 & 32.1 \\
\hline 3 & 5.0 & 37.4 & 66.0 & 94.7 & 123.3 & 8.8 & 29.8 \\
\hline 4 & 7.5 & 36.9 & 64.4 & 91.9 & 119.4 & 9.4 & 28.8 \\
\hline 5 & 10.0 & 36.3 & 63.3 & 90.2 & 117.1 & 9.4 & 28.3 \\
\hline 6 & 12.5 & 35.8 & 61.7 & 87.7 & 113.6 & 9.9 & 27.4 \\
\hline 7 & 16.7 & 35.9 & 60.4 & 84.9 & 109.4 & 11.4 & 26.1 \\
\hline 8 & 25.0 & 32.3 & 52.9 & 73.5 & 94.1 & 11.7 & 24.4 \\
\hline 9 & 33.3 & 31.2 & 48.9 & 66.6 & 84.3 & 13.5 & 21.5 \\
\hline 10 & 37.5 & 30.7 & 46.5 & 62.4 & 78.2 & 14.8 & 17.6 \\
\hline 11 & 41.6 & 30.8 & 46.5 & 62.2 & 77.8 & 15.1 & 17.4 \\
\hline 12 & 50.0 & 30.5 & 45.5 & 60.4 & 75.3 & 15.6 & 16.6 \\
\hline
\end{tabular}

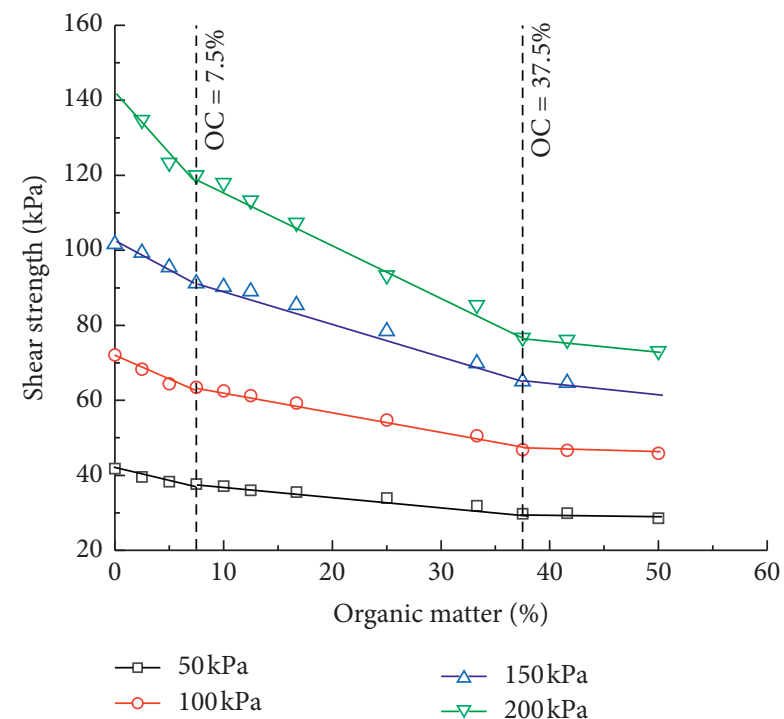

FIgURE 9: Relationship between organic matter content and shear strength under different vertical pressures.

bonding in soil science (Figure 11). The organic matter firmly absorbed by the mineral particles on the soil particles' surface is called the bound organic matter, and the organic matter far away from the mineral particles and not affected by adsorption is called the free organic matter [37].

According to the above analysis, it can be concluded that as the content of organic matter increases, there is a threshold between different forms of organic matter (bound state and free state). When the organic matter content in the soil is lower than the threshold, the organic matter mainly exists in the combined state; when the organic matter content exceeds the threshold, the mineral soil's adsorption capacity for organic matter reaches saturation and free organic matter increases (Figure 12).

Due to the interaction between organic matter and minerals, different forms of organic matter (bound and free) will affect the physical properties of the soil. According to the results of this paper, the impact is mainly reflected in the moisture content and the Atterberg limit. Atterberg limit is the boundary water content that divides the soil consistency state and is closely related to the water content in the soil. Because humus is a hydrophilic colloidal substance, the Atterberg limit and moisture content of clay soil increase with the increase of organic matter (humus) content. However, bound organic matter is adsorbed by mineral particles, and its adsorption capacity for water is relatively weak, while the free organic matter is more free than bound organic matter and has a relatively strong adsorption capacity for water. It can be seen from the results of this test that the water adsorption capacity of the clayey soil had changed when $\mathrm{OC}=7.5 \%$. Therefore, $\mathrm{OC}=7.5 \%$ may be the limit value of bound organic matter and free organic matter. When $\mathrm{OC}<7.5 \%$, minerals and organic matter adsorb each other, organic matter exists in the form of the bound state, and the adsorption capacity for water is weak; when $\mathrm{OC}=7.5 \%$, bound organic matter reaches saturation; when OC $>7.5 \%$, the free organic matter gradually increases and the water adsorption capacity increases.

The shear properties of clays are different from the Atterberg limit and moisture content. The cohesion of clay mainly depends on factors such as the cementation between soil particles and electrostatic gravitational effect; the friction angle mainly depends on the coarseness and arrangement of the surface of the soil particles. The content of organic matter increased from $0 \%$ to $7.5 \%$; the combined organic matter has little effect on the cementation between soil particles and the arrangement of soil particles. Therefore, the cohesion and friction angle of clay show similar properties to minerals. As the organic matter content increased from $7.5 \%$ to $37.5 \%$, the free organic matter gradually increased between the soil particles. The free organic matter played a role in connecting and also played a role in "lubricating" the soil particles. The cohesion and friction angle of clay have a certain impact. The soil is affected by the combined action of minerals and free organic matter, showing the nature of mineral-organic matter. With the further increase of organic matter content (OC $>37.5 \%$ ), the free organic matter between soil particles far exceeds the bound organic matter, resulting in a reduction in contact points between soil particles and a significant change in their arrangement. Therefore, the friction angle of clay is reduced. The colloidal humus significantly improves the cementation between the particles, increasing 


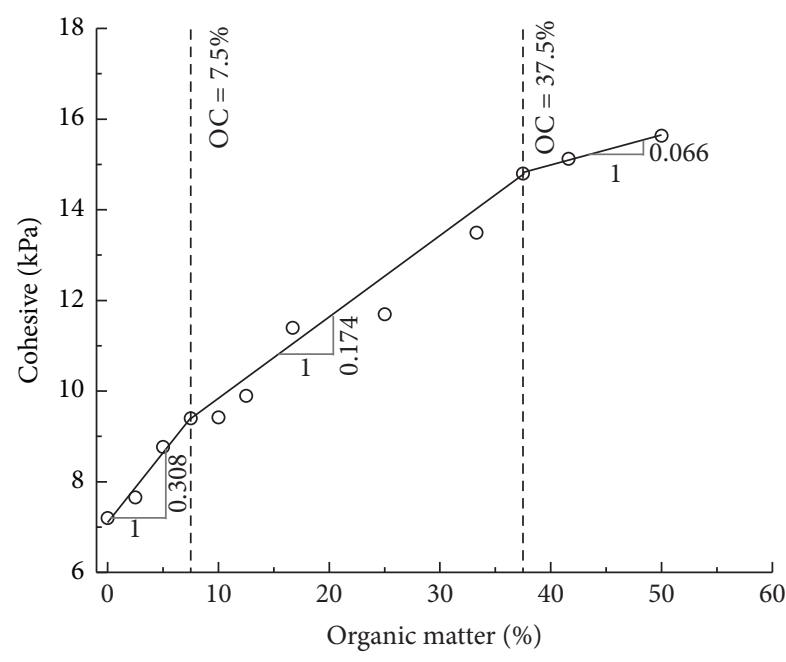

(a)

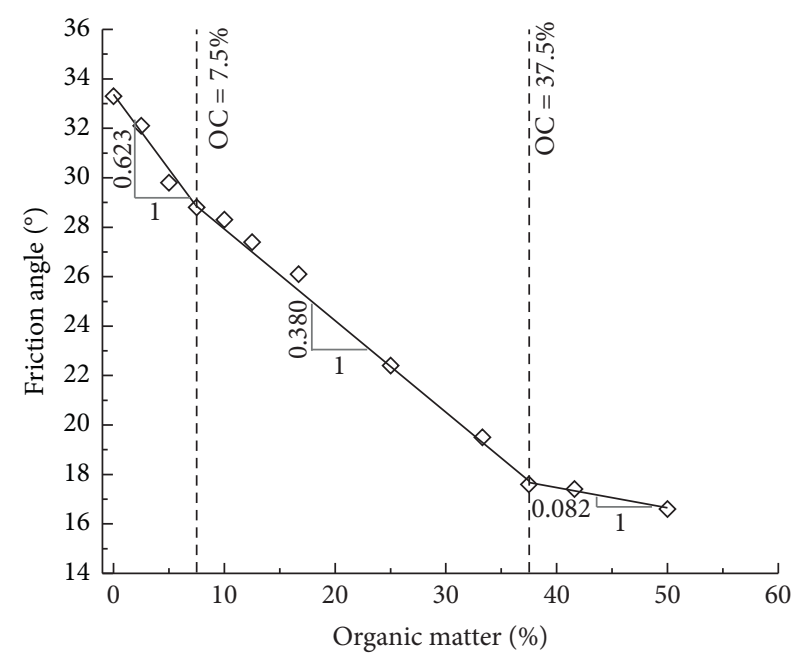

(b)

FIgURE 10: Relationship between organic matter content and cohesion and friction angle. (a) Cohesion. (b) Friction angle.

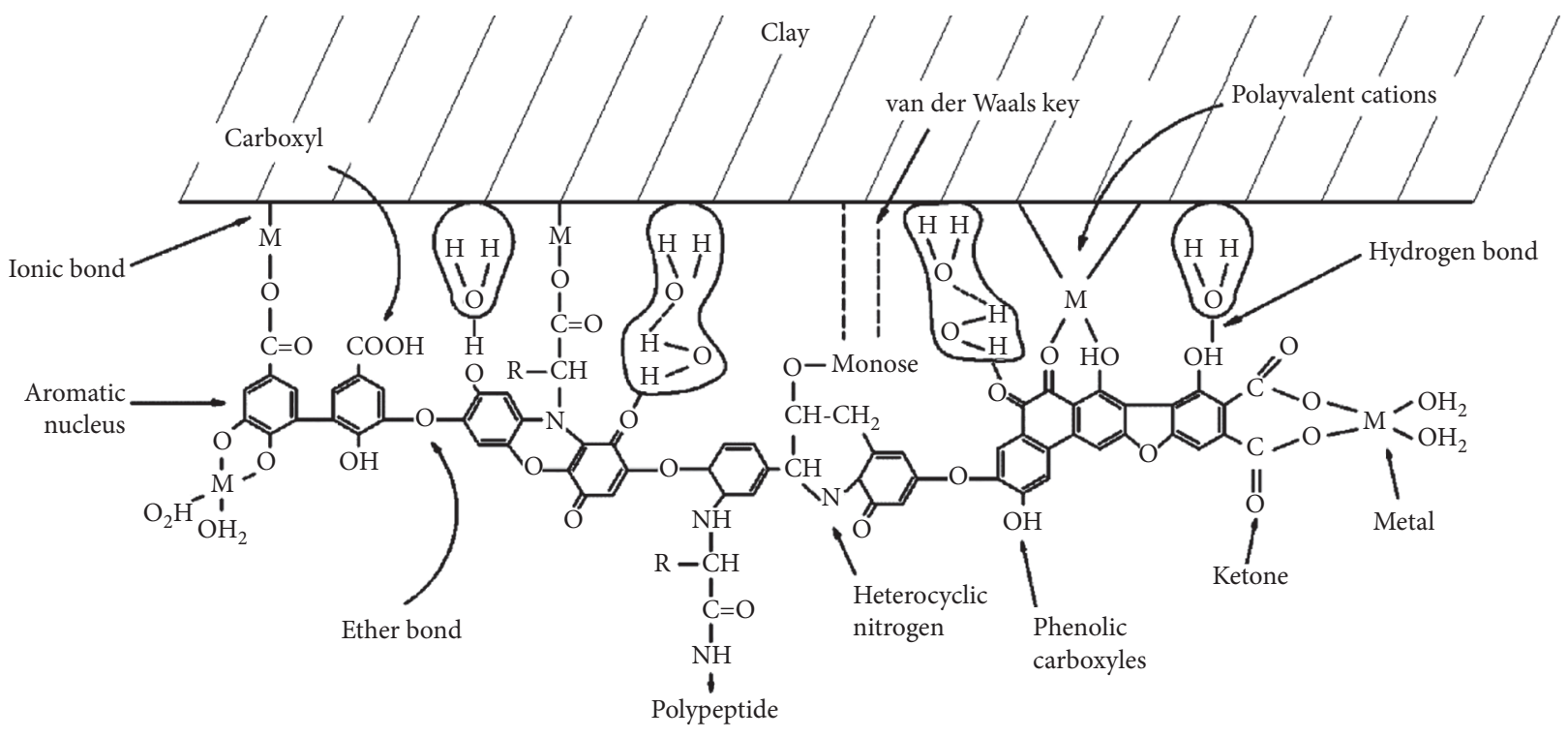

Figure 11: Clay mineral-humus complex [37].
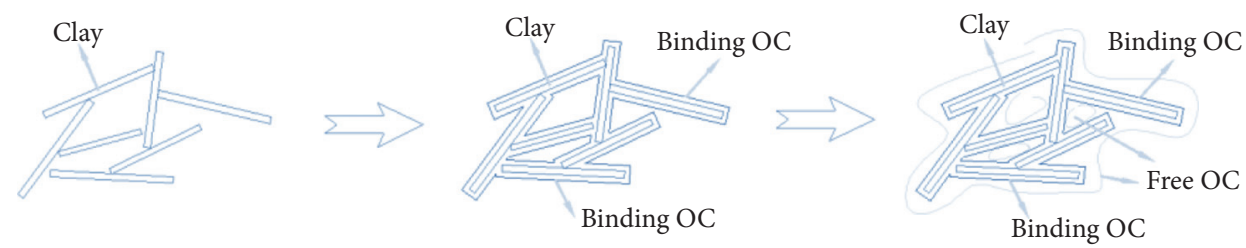

FIGURE 12: Schematic diagram of different adsorption patterns of organic matter. 
the cohesion of the clay soil. At this stage, the clay is mainly affected by free organic matter and exhibits the properties of free organic matter.

\section{Conclusions}

(1) The organic matter content in the soil has a linear relationship with specific gravity and void ratio. The specific gravity decreases with the increase of organic matter content, and the void ratio increases with the increase of organic matter content; the moisture content and Atterberg limit increase with the increase of organic matter content, but turned at $\mathrm{OC}=7.5 \%$, and the change rate increased. As the organic matter content increases, the cohesion increases, the friction angle decreases, and the shear strength decreases. When $\mathrm{OC}=7.5 \%$ and $\mathrm{OC}=37.5 \%$, the cohesion, friction angle, and shear strength have obvious transitions.

(2) The change rule of water content and Atterberg limit with organic matter content shows that $\mathrm{OC}=7.5 \%$ is the threshold of the change of water absorption capacity of clay. When OC $\leq 7.5 \%$, the organic matter is in a bound state. When OC $>7.5 \%$, the bound organic matter is saturated and the free organic matter increases.

(3) Under different organic matter content, the difference in the interaction between organic matter and soil particles leads to the difference in shear characteristics of clay. When the organic matter content is less than $7.5 \%$, the clay soil exhibits mineral properties; when the organic matter content is $7.5 \%$ $37.5 \%$, the clay soil exhibits the properties of mineral-free organic matter; when the organic matter content exceeds $37.5 \%$, the clay soil exhibits nature of free organic matter.

\section{Data Availability}

The data used to support the findings of this study are included within the article.

\section{Conflicts of Interest}

The authors declare that they have no conflicts of interest.

\section{Acknowledgments}

This work was supported by the National Natural Science Foundation of China (nos. 51568030 and 51768027) and the Yunnan Basic Research Key Project (no. 2018BC013).

\section{References}

[1] G. Mesri, T. D. Stark, M. A. Ajlouni, and C. S. Chen, "Secondary compression of peat with or without surcharging," Journal of Geotechnical and Geoenvironmental Engineering, vol. 123, no. 5, pp. 411-421, 1997.

[2] H. Tremblay, J. Duchesne, J. Locat, and S. Leroueil, "Influence of the nature of organic compounds on fine soil stabilization with cement," Canadian Geotechnical Journal, vol. 39, no. 3, pp. 535-546, 2002.

[3] M. Santagata, A. Bobet, C. T. Johnston, and J. Hwang, "One-dimensional compression behavior of a soil with high organic matter content," Journal of Geotechnical and Geoenvironmental Engineering, vol. 134, no. 1, pp. 1-13, 2008.

[4] R. Zentar, N. E. Abriak, and V. Dubois, "Effects of salts and organic matter on Atterberg limits of dredged marine sediments," Applied Clay Science, vol. 42, no. 3-4, pp. 391-397, 2009.

[5] L. Samson and P. L. Rochelle, "Design and performance of an expressway constructed over peat by preloading," Canadian Geotechnical Journal, vol. 9, no. 4, pp. 447-466, 1972.

[6] M. S. Islam and R. Hashim, "Bearing capacity of stabilised tropical peat by deep mixing method," Australian Journal of Basic and Applied Sciences, vol. 3, no. 2, pp. 682-688, 2009.

[7] A. Karunawardena and M. Toki, "Design and performance of highway embankments constructed over Sri Lankan peaty soils," International Journal of Integrated Engineering, vol. 6, no. 2, 2014.

[8] A. W. Skempton and D. J. Petley, "Ignition loss and other properties of peats and clays from Avonmouth, King's Lynn and Cranberry moss," Géotechnique, vol. 20, no. 4, pp. 343-356, 1970.

[9] R. Pusch, Influence of Organic Matter on the Geotechnical Properties of Clays, The National Academies of Sciences, Engineering, and Medicine, Stockholm, Sweden, National Swedish Building Research Summaries, 1973.

[10] B. W. Murphy, "Impact of soil organic matter on soil properties-a review with emphasis on Australian soils," Soil Research, vol. 53, no. 6, p. 605, 2015.

[11] R. T. Odell, T. H. Thornburn, and L. J. Mckenzie, "Relationships of Atterberg limits to some other properties of Illinois soils," Soil Science Society of America Journal, vol. 24, no. $4,1960$.

[12] W. H. Busch and G. H. Keller, "The physical properties of Peru-Chile continental margin sediments-the influence of coastal upwelling on sediment properties," Journal of Sedimentary Research, vol. 51, no. 3, pp. 705-719, 1981.

[13] R. H. Bennett, L. Lehman, M. H. Hulbert et al., "Interrelationships of organic carbon and submarine sediment geotechnical properties," Marine Geotechnology, vol. 6, no. 1, pp. 61-98, 1985.

[14] M. Olgun and M. Yıldiz, "Effect of organic fluids on the geotechnical behavior of a highly plastic clayey soil," Applied Clay Science, vol. 48, no. 4, pp. 0-621, 2010.

[15] L.-L. Zeng, Z.-S. Hong, C. Wang, and Z.-Z. Yang, "Experimental study on physical properties of clays with organic matter soluble and insoluble in water," Applied Clay Science, vol. 132-133, pp. 660-667, 2016.

[16] M. A. Rashid and J. D. Brown, "Influence of marine organic compounds on the engineering properties of a remoulded sediment," Engineering Geology, vol. 9, no. 2, pp. 141-154, 1975.

[17] J. S. Booth and A. G. Dahl, "A note on the relationships between organic matter and some geotechnical properties of a marine sediment," Marine Geotechnology, vol. 6, no. 3, pp. 281-297, 1986.

[18] T. Qiang, G. Fan, G. Yufeng, and K. Takeshi, "Desorption characteristics of $\mathrm{Cr}(\mathrm{III}), \mathrm{Mn}(\mathrm{II})$, and $\mathrm{Ni}(\mathrm{II})$ in contaminated soil using citric acid and citric acid-containing wastewater," Soils and Foundations, vol. 58, no. 1, pp. 50-64, 2018.

[19] Q. Tang, F. Gu, Y. Zhang, Y. Zhang, and J. Mo, "Impact of biological clogging on the barrier performance of landfill 
liners," Journal of Environmental Management, vol. 222, no. 15, pp. 44-53, 2018.

[20] M. K. Hameedi, M. Y. Fattah, and R. R. Al-Omari, "Creep characteristics and pore water pressure changes during loading of water storage tank on soft organic soil," International Journal of Geotechnical Engineering, vol. 14, no. 5, pp. 527-537, 2019.

[21] M. K. Hameedi, R. R. Al-Omari, and M. Y. Fattah, "Compression and creep indices of organic clayey soil," IOP Conference Series: Materials Science and Engineering, vol. 671, Article ID 012035, 2020.

[22] M. Y. Fattah, H. H. Baqir, and O. F. Al-Rawi, "Field and laboratory evaluation of a soft clay southern Iraq," in Proceedings of the 4th Jordanian Civil Engineering Conference, pp. 109-116, Amman, Jordan, March 2006.

[23] H. Yamaguch1, Y. Ohira, K. Kogue, and S. Mori, "Undrained shear characteristics of normally consolidated peat under triaxial compression and extension conditions," Soils \& Foundations, vol. 25, no. 3, pp. 1-18, 1985.

[24] B. B. K. Huat, A. Afshin, and S. Kazemian, "Experimental investigation on geomechanical properties of tropical organic soils and peat," American Journal of Engineering \& Applied Sciences, vol. 2, no. 1, pp. 184-188, 2009.

[25] K. Badv and T. Sayadian, "An investigation into the geotechnical characteristics of Urmia Peat," Iranian Journal of Science \& Technology Transactions of Civil Engineering, vol. 36, no. 2, pp. 167-180, 2012.

[26] ASTM, ASTM D2974-14, Standard Test Methods for Moisture, Ash, and Organic Matter of Peat and Other Organic Soils, ASTM International, West Conshohocken, PA, USA, 2014.

[27] ASTM, ASTM D1997-13, Standard Test Method for Laboratory Determination of the Fiber Content of Peat Samples by Dry Mass, ASTM International, West Conshohocken, PA, USA, 2013.

[28] ASTM, ASTM D4427-13, Standard Classification of Peat Samples by Laboratory Testing, ASTM International, West Conshohocken, PA, USA, 2013.

[29] L. D. Whittig and W. R. Allardice, X-Ray Diffraction Techniques, pp. 331-362, American Society of Agronomy Soil Science Society of America, Madison, WI, USA, 1986.

[30] ASTM, ASTM D854-14, Standard Test Methods for Specific Gravity of Soil Solids by Water Pycnometer, ASTM International, West Conshohocken, PA, USA, 2014.

[31] ASTM, ASTM D4318-17, Standard Test Methods for Liquid Limit, Plastic Limit, and Plasticity Index of Soils, ASTM International, West Conshohocken, PA, USA, 2017.

[32] M. Long, "Review of peat strength, peat characterisation and constitutive modelling of peat with reference to landslides," Studia Geotechnica et Mechanica, vol. 27, no. 3, pp. 67-90, 2005.

[33] ASTM, ASTM D3080/D3080M-11, Standard Test Method for Direct Shear Test of Soils under Consolidated Drained Conditions, ASTM International, West Conshohocken, PA, USA, 2011.

[34] W. P. McDonald, "Influence of organic matter on the geotechnical properties and consolidation characteristics of Northern Oregon continental slope sediments," American Journal of Physiology, vol. 272, no. 5, pp. 1577-R1587, 1982.

[35] A. J. Puppala, S. P. Pokala, N. Intharasombat, and R. Williammee, "Effects of organic matter on physical, strength, and volume change properties of compost amended expansive clay," Journal of Geotechnical and Geoenvironmental Engineering, vol. 133, no. 11, pp. 1449-1461, 2007.
[36] F. Hamouche and R. Zentar, "Effects of organic matter on mechanical properties of dredged sediments for beneficial use in road construction," Environmental Technology, vol. 41, no. 3, pp. 296-308, 2018

[37] C. Y. Huang, Soil Science, p. 211, China Agriculture Press, Beijing, China, 2000.

[38] G. H. Keller, "Organic matter and the geotechnical properties of submarine sediments," Geo-Marine Letters, vol. 2, no. 3-4, pp. 191-198, 1982.

[39] T.. , E. Adejumo, "Effect of organic content on compaction and consolidation characteristics of lagos organic clay," Electronic Journal of Geotechnical Engineering, vol. 17, pp. 2201-2211, 2012.

[40] F. Hamouche and R. Zentar, "Effects of organic matter on physical properties of dredged marine sediments," Waste and Biomass Valorization, vol. 11, no. 1, pp. 389-401, 2018.

[41] H. F. Pulat and Y. Yukselen-Aksoy, "Factors affecting the shear strength behavior of municipal solid wastes," Waste Management, vol. 69, pp. 215-224, 2017.

[42] J. A. Braida, J. M. Reichert, D. J. Reinert, and J. M. D. Soares, "Coesão e atrito interno associados aos teores de carbono orgânico e de água de um solo franco arenoso," Ciência Rural, vol. 37, no. 6, pp. 1646-1653, 2007.

[43] T. B. Edil and X. Wang, "Shear strength and $K_{o}$ of peats and organic soils," Geotechnics of High Water Content Materials, pp. 209-225, 2000. 